\title{
DISCURSO DA DIGNÍSSIMA DIRETORA DA ESCOLA DE ENFERMAGEM DE RIBEIRÃO PRETO DA UNIVERSIDADE DE SÃO PAULO
}

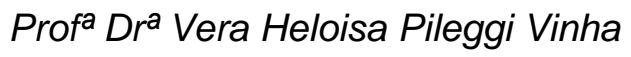

Excelentíssimas autoridades presentes ou representadas, prezadas colegas, Senhoras e Senhores:

A Escola de Enfermagem de Ribeirão Preto está comemorando o seu quadragésimo aniversario. Quarenta anos de trabalho e de luta na busca de um objetivo maior, formar recursos humanos capazes de exercer dignamente a profissão de enfermagem. Mas, para atingir tal objetivo, cada um contribuiu com a tarefa que the competia. A união de esforços e o compromisso coletivo fizeram com que a nossa Escola viesse a ocupar a posição de destaque entre as 104 existentes no país, e a primeira da América Latina a ser reconhecida pela Organização Mundial de Saúde como Centro de Excelência, titulo que Ihe foi outorgado como reconhecimento pelo nível do trabalho que desenvolve no ensino, na pesquisa, na extensão dos serviços que presta a comunidade.

Analisando à situação sob uma ótica retrospectiva pode se afirmar que todos os servidores desta unidade, nos exercícios de suas funções docentes, técnicas e administrativas deram as suas contribuições e todos nós hoje nos regozijamos interiormente e nos sentimos altivos, porque de alguma maneira contribuímos para a construção de nossa Escola.

Neste momento há muito de alegria para ser registrado, por pertencermos a USP, a Escola de Enfermagem de Ribeirão Preto, por sermos Enfermeiros e acima de tudo por estarmos fornecendo profissionais competentes originados de diferentes camadas sociais do nosso país, das Américas e da África. É dever de consciência agradecer o apoio que veio de todos os lados, acima de tudo da USP da qual nos orgulhamos por ser a maior Universidade do país; ao seu Magnífico Vice-Reitor em exercício aqui presente, o Prof. Dr. Ruy Laurenti e ao Ex-Reitor Prof. Dr. Roberto Leal Lobo e Silva Filho, por terem conseguido fazer com que a nossa USP continuasse a crescer apesar da situação econômica tão hostil, porque vem passando o país; aos demais reitores que em passado recente ou remoto nunca faltaram com 
o necessário aval para que nossa Escola se emancipasse; as autoridades do município de Ribeirão Preto que continuam se orgulhando de suas escolas de nível superior entre as quais nós nos colocamos; as agencias de financiamento e fomento de ensino e a pesquisa, FAPESP, CNPq e CAPES que com suas ajudas tornaram possível dilatar os horizontes intelectuais, cientificas e de cultura geral de nossos docentes; a sociedade como um todo que durante estes 40 anos tem confiado seus filhos para serem formados por nós.

Aos nossos docentes de hoje, de ontem e do passado mais remoto que deram as suas juventudes e suas maturidades em prol do ensino da Enfermagem nos vários campos de ensino; aos nossos funcionários que igualmente deram o melhor de si para que nossa Escola se tornasse forte, sem seus apoios e trabalhos provavelmente não estaríamos aqui nesta sessão solene. Agradeço finalmente aos Membros da Comissão de Cultura e Extensão Universitária da nossa Unidade a Comissão Organizadora que tornaram possível a realização desse evento. Pelo muito que atual Reitoria fez a nossa Escola em nome do seu corpo docente e dos funcionários quero entregar ao Magnífico Vice-Reitor em exercício uma lembrança desta data. 